\section{Apple Tree Rootstock and Fertilizer Application Timing Affect Nitrogen Uptake}

\author{
Paula B. Aguirre', Yahya K. Al-Hinai', Teryl R. Roper², and \\ Armand R. Krueger ${ }^{3}$ \\ Department of Horticulture, University of Wisconsin-Madison, Madison, \\ WI 53705
}

Additional index words. nitrogen, rootstocks, ${ }^{15} \mathrm{~N}, \mathrm{~N}$ cycling, nutrient uptake

Abstract. Nitrogen (N) uptake was compared on 10 dwarf apple rootstocks (M.9 EMLA, M.26 EMLA, M.27 EMLA, M.9 RN29, Pajam 1, Pajam 2, B.9, Mark, B.469, and M.9 T337) grafted with the same scion ('Gala') in a four year-old orchard. Trees were treated in either Spring or Fall 1998 with $40 \mathrm{~g}$ of soil applied actual $\mathrm{N}$ per tree using ammonium nitrate enriched to $1 \%{ }^{15} \mathrm{~N}$. Both percentage of $\mathrm{N}(\% \mathrm{~N})$ and $\mathrm{N}$ from fertilizer $(\mathrm{NFF})$ in leaf tissue were highly affected by the rootstock and the season of $\mathrm{N}$ application. Generally, higher $\% \mathrm{~N}$ and NFF were observed for spring than fall applications, except for leaves collected during early June 1998. Generally, M.26 EMLA, M.27 EMLA, and M.9 RN29 were the most efficient rootstocks in $\mathrm{N}$ uptake for spring applied nitrogen. M.9 EMLA was most efficient late in the season following fall application. Mark was more efficient early in the season for fall applied $\mathbf{N}$ than spring application. However, trees on Mark rootstock had the lowest $\% \mathrm{~N}$ throughout the season regardless of the time of $\mathrm{N}$ application. Pajam 1 and Pajam 2 were the least efficient rootstocks in $\mathrm{N}$ uptake following fall $\mathrm{N}$ application. Rootstock also significantly affected $\% \mathrm{~N}$ and $\mathrm{NFF}$ of wood tissue. Generally, trees on B.469 had the highest $\% \mathrm{~N}$ in their wood regardless of the season of application. No single rootstock had consistently higher $\mathbf{N}$ from fertilizer in their wood tissue after spring application. At the May 1999 sampling date, M.26 EMLA had higher NFF than M.27 EMLA, Pajam 1, Pajam 2, and B.9 with a fall application. Other rootstocks were intermediate. Samples collected in August showed that Pajam 1 was the least efficient rootstock in $\mathbf{N}$ uptake for fall applied $\mathbf{N}$ compared to other rootstocks, except for Pajam 2 and B.9 that were intermediate. Leaf and wood tissue analysis showed that different rootstocks had different $N$ uptake efficiencies throughout the season. Generally, M.26 EMLA, M.27 EMLA, M.9 RN29 and M.9 EMLA were more efficient at $\mathrm{N}$ uptake regardless the season of $\mathrm{N}$ application. Pajam 1 and Pajam 2 were the least efficient.

Efficient fertilizer practices not only increase the yield and profitability of crops, but also avoid environmental contamination. Optimum nutrient management in deciduous fruit crops can be achieved by knowing the periods of greatest absorption and assessing the nitrogen $(\mathrm{N})$ demand of the tree.

Early season growth of apple trees depends mainly on internal cycling of $\mathrm{N}$ reserves that were stored in woody tissue before leaf fall (Hill-Cottigham and Lloyd-Jones, 1975; Millard and Thomson, 1989; Titus and Kang, 1982; Tromp and Ovaa, 1973). For this reason, the relative contribution of fertilizer $\mathrm{N}$ is not easy to assess.

Nitrogen cycling in deciduous fruit crops has been documented using ${ }^{15} \mathrm{~N}$ tracer techniques. Most of this work has used young trees grown in pots (Hill-Cottigham and Lloyd-Jones, 1975; Millard and Thomson,

Received for publication 27 Oct. 2000. Accepted for publication 10 Mar. 2001. Partial support provided by the College of Agricultural and Life Sciences, Univ. of Wisconsin-Madison.

${ }^{1}$ Graduate Research Assistant.

${ }^{2}$ Professor, to whom reprint requests should be addressed.

${ }^{3}$ Senior Research Specialist.
1989; Tagliavini et al., 1997; Weinbaum et al., 1984) rather than mature trees (Khemira et al., 1998; Sanchez et al., 1990, 1991, 1992; Weinbaum et al., 1984).

Remobilization of $\mathrm{N}$ ended between petal fall and the beginning of fruit development in 1-year-old pear (Pyrus communis L.) trees while $\mathrm{N}$ uptake started before the end of remobilization of stored $\mathrm{N}$ (Tagliavini et al., 1997). However, Sanchez et al. (1990) observed that soil derived $\mathrm{N}$ became important for fruit growth after fruit set in a 6-year-old pear tree.

Plant recovery of ${ }^{15} \mathrm{~N}$ has been studied in different fruit trees. Recovery of applied $\mathrm{N}$ was between $27.8 \%$ and $33.9 \%$ in new growth of five-year old pear trees (Sanchez et al., 1990 ), and $32 \%$ recovery was observed in new growth of 3-year-old peach trees (Prunus persica L.) (Muños et al., 1993). Lower values (6\% to $14.3 \%$ ) were obtained for shoot leaves of a 9-year-old apple tree (Khemira et al., 1998), reflecting the increased contribution of cycling $\mathrm{N}$ as trees age. Sanchez et al. (1990) found that total contribution of $\mathrm{N}$ fertilizer applied in spring was about half of soil derived $\mathrm{N}$.

Several reports indicate higher reserve $\mathrm{N}$ levels following $\mathrm{N}$ application made in late summer or fall. Mature almond trees (Prunus amygdalus L.) grown in sandy soil showed an inverse relationship between date of application and leaf tissue enrichment from labeled fertilizer applied the previous season (Weinbaum et al., 1984). Young apple (Malus $\times$ domestica Borkh) trees grown in pots also showed a clear seasonal effect for nitrate uptake, with the highest recovery observed for the August application (60\%), followed by March (40\%), and the lowest recovery after October application (16\%) (Hill-Cottingham and Lloyd-Jones, 1975).

In a recent publication using mature apple trees to study $\mathrm{N}$ timing and partitioning, Khemira et al. (1998) showed that spring N treatment partitioned to fruit, leaves, and shoots, while late summer application favored roots. However, preharvest application of ${ }^{15} \mathrm{~N}$ showed highest recoveries in leaf and shoots the year after application and showed higher utilization efficiency than spring treatments.

New size controlling apple rootstocks have been introduced during the last several years. However, detailed comparisons of $\mathrm{N}$ uptake ability of these apple rootstocks remain unreported. The objective of this research was to evaluate differences in $\mathrm{N}$ recovery between ten different apple rootstocks and to determine the effect of application timing on $\mathrm{N}$ uptake and recovery.

\section{Materials and Methods}

This research was conducted at the Peninsular Agricultural Research Station near Sturgeon Bay, Wis., on a Longrie sandy loam (coarse, loamy, mixed, frigid, Entic Haplorthod) soil, $\mathrm{pH} \approx 7$ with $4 \%$ organic matter. The orchard was planted in 1994 with apple trees grafted to the same scion ('Gala'). Ten different dwarfing rootstocks (M.9EMLA, M.26 EMLA, M.27 EMLA, M.9 RN29, Pajam 1, Pajam 2, B.9, Mark, B.469, and M.9 T337) were used in this research. The orchard was maintained according to protocols established for the previously existing NC-140 project. Trees were trained to a central axe system. Alleys between rows were planted to a grass sod and a 2-m-wide weed-free area within the tree row was maintained with herbicides.

Ammonium nitrate $\left(\mathrm{NH}_{4} \mathrm{NO}_{3}\right)$ enriched to $1 \%{ }^{15} \mathrm{~N}$ in the nitrate fraction was applied at a rate of $40 \mathrm{~g}$ actual $\mathrm{N}$ per tree. Fertilizer was applied in water in the drip zone with watering cans either in early May (before leaf emergence) or October (postharvest) of 1998. Treatments were replicated four times with an additional unlabeled fertilizer control on separate trees to assess possible changes in the natural abundance of ${ }^{15} \mathrm{~N}$ at each application date. The experimental design was a split plot design with application time as whole plot and rootstock as the split plot.

Leaf tissue samples consisted of ten fully expanded leaves in the midsection of current season growth and were collected monthly in 1998 for spring application and 1999 for fall application. Wood samples were three terminal wood samples per tree collected in May, Aug., and Oct. 1999, regardless of year of 
treatment. Samples were dried in a forced-air oven at $65^{\circ} \mathrm{C}$ to constant weight and ground to 40 -mesh in a Wiley mill. Total $\mathrm{N}$ was determined by dry combustion (Bremner, 1996) using a Carlo Erba analyzer (Milan, Italy) and ${ }^{15} \mathrm{~N}$ determined on the resulting $\mathrm{N}_{2}$ gas using a Europa Scientific Tracer Mass spectrometer (Crew, Cheshire, U.K.).

Values of N recovery from fertilizer (NFF) were calculated using the following equation, adapted from Hauck and Bremner (1976):

$$
\begin{aligned}
\mathrm{NFF}= & \left({ }^{15} \mathrm{~N}_{\text {natural abundance }}-\text { atom } \%{ }^{15} \mathrm{~N}\right)_{\text {tissue }} / \\
& \left({ }^{15} \mathrm{~N}_{\text {natural abundance }}-\text { atom\% }{ }^{15} \mathrm{~N}\right)_{\text {fertilizer }}
\end{aligned}
$$

Natural abundance of the tissue was determined by control and pretreatment samples. The natural abundance of unlabeled $\mathrm{N}$ fertilizer was $0.366 \%$.

Data were subjected to analysis of variance (ANOVA) and mean separation by Duncan's multiple range test following a significant $\mathrm{F}$ test.

\section{Results and Discussion}

Nitrogen uptake in apple trees expressed as leaf $\mathrm{N}$ concentration or $\mathrm{N}$ from fertilizer (NFF) were significantly affected by the season of $\mathrm{N}$ application, rootstock, and the date of sampling (Table 1). Significant season of application $\times$ rootstock and season of application $\times$ sample date interactions were found. Generally, higher percentage of $\mathrm{N}$ and ${ }^{15} \mathrm{~N}$ recovery were observed for the spring than fall applied $\mathrm{N}$, except for samples collected during early June 1998 (Fig. 1 A and B). This could be due to partitioning of spring applied $\mathrm{N}$ to leaves, shoots and fruits compared to fall applied N, which favored roots (Khemira et al., 1998). Percentage of leaf $\mathrm{N}$ during early June was low, perhaps because fruit growth, shoot growth and flower bud initiation all occur at the same time, and competition for substrates occurs among these sinks (Millard and Thomson, 1989). For spring applied N, $\% \mathrm{~N}$ in leaves of trees on M.26 EMLA, Pajam 1 , and B.469 was higher in July compared to Pajam 2, B.9 and Mark rootstocks (Table 2). Other rootstocks were intermediate.

Fall-applied N resulted in trees on M.27 EMLA, Pajam 1, B.9, and B.469 having higher leaf $\% \mathrm{~N}$ compared to M.26 EMLA, Pajam 2, or Mark rootstocks (Table 2). M.9 RN29 and M.9 T337 were intermediate. Percent N in leaves declined from August to October likely due to dilution and remobilization of some $\mathrm{N}$ for root growth or storage after leaf growth had slowed (Millard and Thomson, 1989).

A better measure of $\mathrm{N}$ uptake efficiency is the nitrogen from fertilizer in the tissues. This is expressed as the ratio of the tissue enrichment of ${ }^{15} \mathrm{~N}$ compared to its natural abundance and the enrichment of the fertilizer compared to its natural abundance. Season of application, rootstock, and sample date were significant (Table 1).

Following spring fertilization, M.9 EMLA and M9.RN29 had more $\mathrm{N}$ from fertilizer (NFF) in leaves compared to Pajam 1, Pajam 2, B.9, B.469, and M.9 T337 rootstocks (Table

Table 1. Analysis of variance table for $\% \mathrm{~N}$ and $\mathrm{N}$ from fertilizer (NFF) of apple ('Gala') leaves as affected by 10 different rootstocks, season of application (Season), sampling month (Sample date), and their interactions. N was applied during May or Oct. 1998 for Spring and fall applications, respectively. Spring and fall samples were collected during Summer 1998 and 1999, respectively. $(n=4)$.

\begin{tabular}{lrrrrrrr}
\hline & \multicolumn{3}{c}{$\% \mathrm{~N}$} & & \multicolumn{3}{c}{${ }^{15} \%$} \\
\cline { 2 - 4 } \cline { 6 - 8 } Source & DF & F value & $P>\mathrm{F}$ & & DF & F value & $P>\mathrm{F}$ \\
\hline Season & 1 & 69.61 & $<0.0001$ & & 1 & 489 & $<0.0001$ \\
Rootstock & 9 & 10.36 & $<0.0001$ & & 9 & 13.29 & $<0.0001$ \\
Season $\times$ rootstock & 9 & 4.67 & $<0.0001$ & & 9 & 5.22 & $<0.0001$ \\
Sample date & 4 & 91.39 & $<0.0001$ & & 4 & 52.63 & $<0.0001$ \\
Season $\times$ sample date & 4 & 93.6 & $<0.0001$ & & 4 & 111.21 & $<0.0001$ \\
Rootstock $\times$ sample date & 36 & 0.83 & 0.7402 & & 36 & 0.83 & 0.7422 \\
Season $\times$ rootstock $\times$ sample date & 36 & 1.16 & 0.2553 & & 36 & 0.9 & 0.6359 \\
Error & 275 & & & & 275 & & \\
Corrected total & 374 & & & 374 & & \\
\hline
\end{tabular}

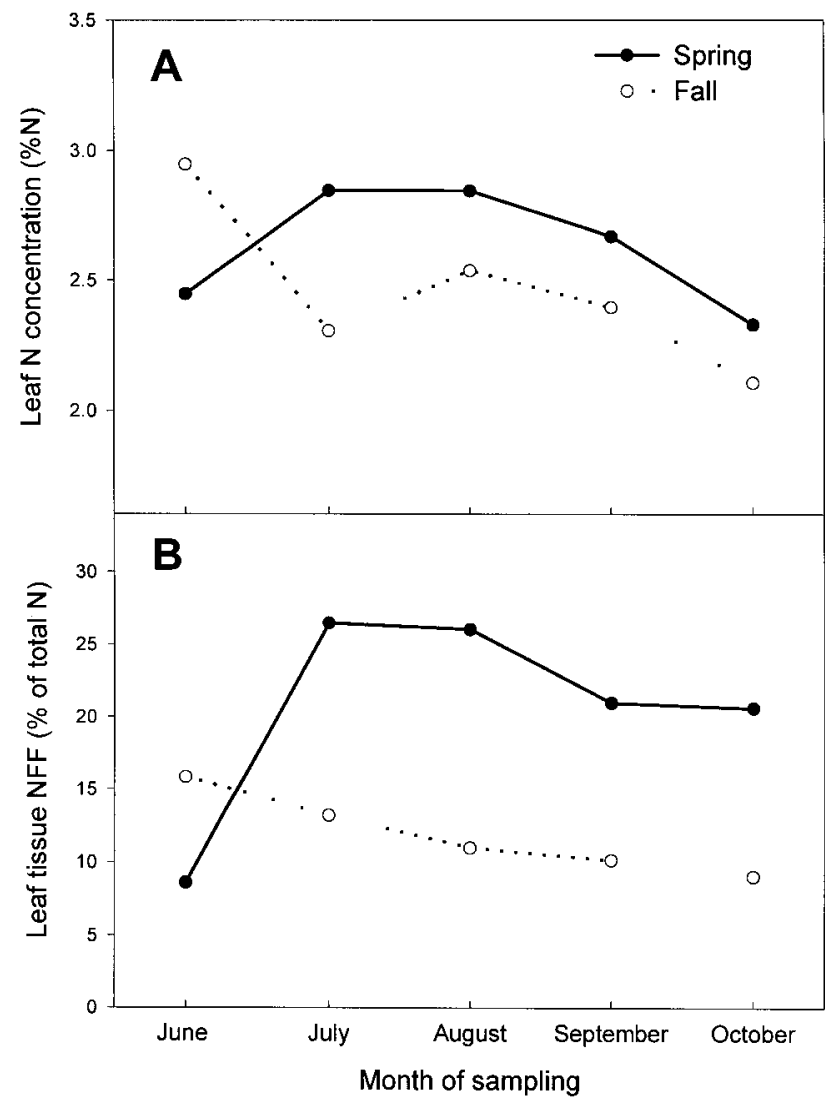

Fig. 1. Effect of date of sample collection on leaf $\mathrm{N}$ concentration $(\mathbf{A})$ and leaf tissue $\mathrm{N}$ from fertilizer $(\mathbf{B})$ in apple ('Gala') grown at Sturgeon Bay, Wis. Closed symbols represent spring application and open symbols represent fall application. Trees received $40 \mathrm{~g}$ actual $\mathrm{N}$ fertilizer enriched to $1 \%$ with ${ }^{15} \mathrm{~N}$ in May 1998 (Spring) or Oct. 1998 (Fall). Spring and fall data were collected during 1998 and 1999, respectively. $(\mathrm{n}=4)$.

2). M.26 EMLA, M.27 EMLA and Mark were intermediate (Table 2). Following fall $\mathrm{N}$ application M.9EMLA, M.26EMLA, Mark, B.469 and M.9 T337 were efficient at recovering N. M.27 EMLA, Pajam 1 and Pajam 2 were least efficient. Dong et al. (1998) also observed higher N uptake in M.9 EMLA and M.26 EMLA rootstocks.

The sampling month had a great effect on the amount of NFF in leaves. Leaf tissue NFF was higher at all sampling dates except June for spring applied $\mathrm{N}$ than for fall applied $\mathrm{N}$ (Fig. $1 \mathrm{~A}$ and B). NFF for the spring treatment was highest in July and then declined through the remainder of the season. NFF for the fall treatment declined gradually throughout the season. This is likely caused by dilution and remobilization. This suggests that for apple rootstocks in cold temperate regions trees are able to take up more of the applied $\mathrm{N}$ following spring application compared to fall application and that spring applied $\mathrm{N}$ is immediately utilized by the vegetative parts of the tree, such as new leaves and shoots.

Five M.9 clones were included in this research. With the exception of M.9 EMLA for fall treatment, the M.9 clones did not have high leaf $\mathrm{N}$ concentration (Table 2). M.9 
Table 2. Nitrogen concentration (\% dry wt) and $\mathrm{N}$ derived from fertilizer (NFF) in apple ('Gala') shoot leaves grown at Sturgeon Bay, Wis. Trees received $40 \mathrm{~g}$ actual $\mathrm{N}$ fertilizer enriched to $1 \%$ with ${ }^{15} \mathrm{~N}$ in May 1998 (Spring) or Oct. 1998 (Fall). Spring and fall samples were collected during 1998 and 1999, respectively. (n=4).

\begin{tabular}{|c|c|c|c|c|c|c|c|c|c|c|c|}
\hline \multirow[b]{2}{*}{$\begin{array}{l}\text { Season of N } \\
\text { application }\end{array}$} & \multicolumn{10}{|c|}{ Rootstock } & \multirow[b]{2}{*}{ Significance } \\
\hline & $\begin{array}{c}\text { M.9 } \\
\text { EMLA }\end{array}$ & $\begin{array}{c}\text { M.26 } \\
\text { EMLA }\end{array}$ & $\begin{array}{c}\text { M.27 } \\
\text { EMLA }\end{array}$ & $\begin{array}{c}\text { M.9 } \\
\text { RN29 }\end{array}$ & Pajam 1 & Pajam 2 & B.9 & Mark & B.469 & $\begin{array}{l}\text { M.9 } \\
\text { T337 }\end{array}$ & \\
\hline $\begin{array}{l}\text { Spring } \\
\text { Fall }\end{array}$ & $\begin{array}{l}---- \\
2.59 \mathrm{~cd}^{\mathrm{y}} \\
2.53 \mathrm{a}-\mathrm{c}\end{array}$ & $\begin{array}{l}---- \\
2.71 \mathrm{ab} \\
2.33 \mathrm{~d}\end{array}$ & $\begin{array}{l}---- \\
2.66 \mathrm{abc} \\
2.67 \mathrm{a}\end{array}$ & $\begin{array}{c}----- \\
2.58 \mathrm{~cd} \\
2.46 \mathrm{~b}-\mathrm{d}\end{array}$ & $\begin{array}{l}\% \text { dry } \\
2.70 \mathrm{ab} \\
2.58 \mathrm{ab}\end{array}$ & $\begin{array}{c}-- \\
2.59 \mathrm{~cd} \\
2.38 \mathrm{~cd}\end{array}$ & $\begin{array}{l}-1-- \\
2.57 \mathrm{~cd} \\
2.58 \mathrm{ab}\end{array}$ & $\begin{array}{c}---- \\
2.50 \mathrm{~d} \\
2.19 \mathrm{e}\end{array}$ & $\begin{array}{c}---- \\
2.74 \mathrm{a} \\
2.58 \mathrm{ab}\end{array}$ & $\begin{array}{l}2.64 \mathrm{bc} \\
2.43 \mathrm{~b}-\mathrm{d}\end{array}$ & $\begin{array}{l}* * * \mathrm{z} \\
* * *\end{array}$ \\
\hline & ---- & ---- & ---- & $-\quad \%$ of to & al $\mathrm{N}$ derive & from fertil & er -- & ---- & ---- & ----- & \\
\hline Spring & $23.16 \mathrm{ab}$ & $22.56 \mathrm{~b}$ & $21.96 \mathrm{~b}$ & $25.62 \mathrm{a}$ & $18.84 \mathrm{c}$ & $18.3 \mathrm{c}$ & $18.12 \mathrm{c}$ & $22.12 \mathrm{~b}$ & $16.09 \mathrm{c}$ & $18.5 \mathrm{c}$ & $* * *$ \\
\hline Fall & $13.17 \mathrm{ab}$ & $13.65 \mathrm{ab}$ & $10.19 \mathrm{c}$ & $13.55 \mathrm{ab}$ & $7.21 \mathrm{~d}$ & $9.66 \mathrm{c}$ & $11.53 \mathrm{bc}$ & $14.3 \mathrm{a}$ & $12.38 \mathrm{ab}$ & $13.22 \mathrm{ab}$ & $* * *$ \\
\hline
\end{tabular}

'Mean separation within rows by Duncan's multiple range test at $P \leq 0.05$.

$2^{* * * *}$ Significant at $P \leq 0.001$.

RN29, Pajam 2, and M.9T337 had low leaf N concentration from either application time. M.9 EMLA and M.9 RN29 had high NFF while Pajam 1 and Pajam 2 always had low NFF. M.9 T337 was mixed, having high NFF following fall application, but not from spring application.

Rootstock significantly affected percentage of $\mathrm{N}(\% \mathrm{~N})$ and NFF of wood tissue (Table 3). Season of $N$ application had a highly significant effect on NFF in wood but not $\% \mathrm{~N}$.

The sample date was highly significant for both $\% \mathrm{~N}$ and NFF of wood tissue. There was also a season by sample date interaction for both measures and a season of application by rootstock interaction for NFF.

Trees on all rootstocks tested had the highest $\% \mathrm{~N}$ in wood during May compared to August or October regardless of the season of $\mathrm{N}$ application (Fig. 2A). There were no significant differences between rootstocks for either spring or fall application (Table 4). The numerical differences are slight and are likely not biologically significant either. Titus and Kang (1982) found that $\mathrm{N}$ was remobilized from apple leaves into the woody portions of trees.

NFF in wood tissue was higher after spring application than fall application perhaps due to fall applied fertilizer being lost through leaching or volatilization (Fig 2B). The lowest NFF for all rootstocks was during May following a spring application with $\approx 50 \%$ less than August or October sampling dates, perhaps due to an early depletion of stored $\mathrm{N}$ caused by the large $\mathrm{N}$ demand of new growth of leaves and flowers. NFF values for fall application were steady at just $<10 \%$ of total N.

Following spring application, M.27 EMLA, M.9 RN29, B.9 and M.9 T337 had the highest NFF. Pajam 1 had the lowest NFF values. Following fall application, M.9 EMLA, M.26 EMLA, and B.469 had the highest NFF while M.27 EMLA, Pajam 1, Pajam 2 and B.9 had the lowest NFF. It is interesting that M.27 EMLA and B.9 were efficient at recovering spring applied $\mathrm{N}$, but not fall applied N. No rootstock was highly efficient at recovering $\mathrm{N}$ from both spring and fall applications.

Some similarities were found for uptake efficiency as reflected by NFF for both leaves and wood samples. M.9 RN29 had high recovery for both leaves and wood following spring application. Pajam 1 was inefficient for both leaves and wood. Following fall application
Table 3. The ANOVA table for percentage ofN and N from fertilizer (NFF) of apple (Gala) wood tissue as affected by ten different rootstocks, season of application (Season), sampling month (Sample date) and their interactions. N was applied during May or Oct. 1998 for Spring and Fall applications, respectively. Spring and Fall samples were collected during Summer 1998 and 1999, respectively. (n=4).

\begin{tabular}{lrrrrrrrr}
\hline & \multicolumn{4}{c}{$\% \mathrm{~N}$} & & \multicolumn{3}{c}{${ }^{15} \mathrm{~N} \%$} \\
\cline { 2 - 3 } \cline { 7 - 9 } Source & DF & F-Value & Pr $>\mathrm{F}$ & & DF & F-Value & Pr $>\mathrm{F}$ \\
\hline Season & 1 & 0.01 & 0.9216 & & 1 & 902.06 & $<0.0001$ \\
Rootstock & 9 & 3.06 & 0.0021 & & 9 & 5.94 & $<0.0001$ \\
Season $\times$ rootstock & 9 & 1.65 & 0.1057 & & 9 & 3.09 & 0.0019 \\
Sample date & 2 & 1023.86 & $<0.0001$ & & 2 & 82.68 & $<0.0001$ \\
Season $\times$ sample date & 2 & 2.97 & 0.0544 & & 2 & 70.66 & $<0.0001$ \\
Rootstock $\times$ sample date & 18 & 1.15 & 0.3110 & & 18 & 1.03 & 0.4311 \\
Season $\times$ rootstock $\times$ sample date & 18 & 1.07 & 0.3843 & & 18 & 0.78 & 0.7258 \\
Error & 156 & & & & 156 & & \\
Corrected total & 215 & & & & 215 & & \\
\hline
\end{tabular}

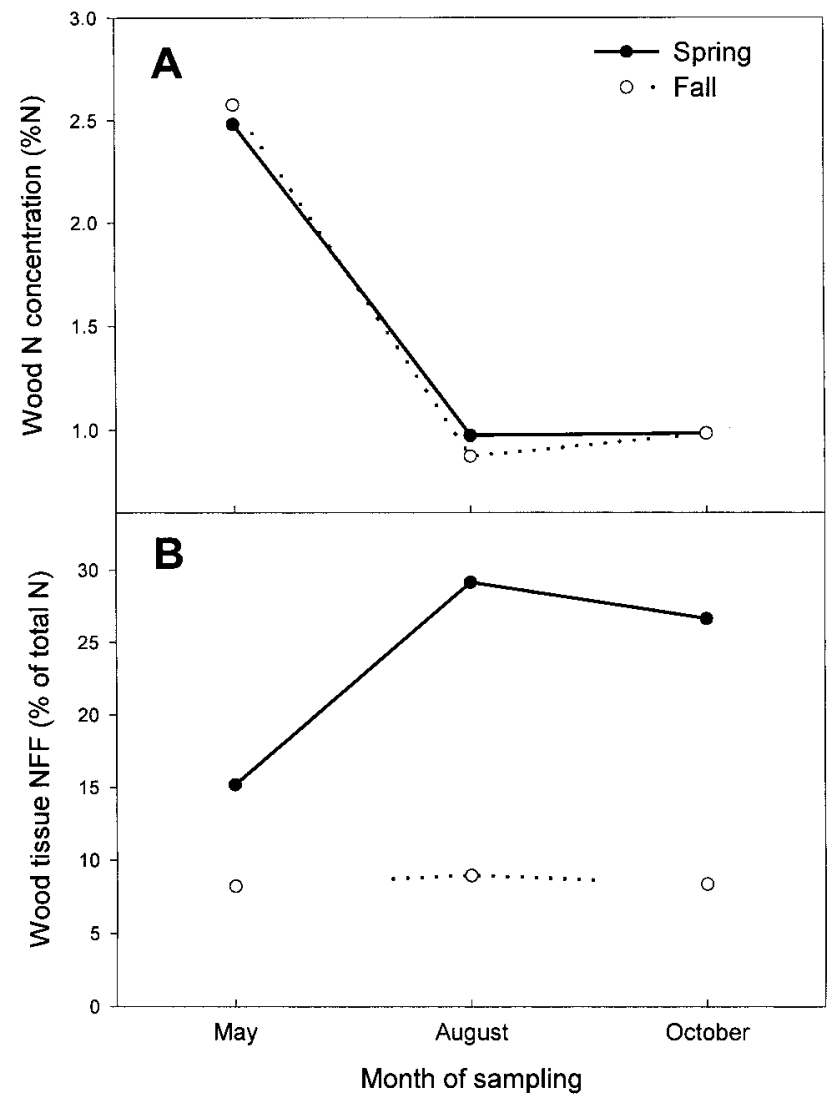

Fig. 2. Effect of date of sample collection on wood $\mathrm{N}$ concentration $(\mathbf{A})$ and wood tissue $\mathrm{N}$ from fertilizer (B) in apple ('Gala') grown at Sturgeon Bay, Wis. Closed symbols represent spring application and open symbols represent fall application. Trees received $40 \mathrm{~g}$ actual $\mathrm{N}$ fertilizer enriched to $1 \%$ with ${ }^{15} \mathrm{~N}$ in May 1998 (Spring) or Oct. 1998 (Fall). Spring and fall data were collected during 1998 and 1999, respectively. $(n=4)$. 
Table 4. Nitrogen concentration (\% dry wt) and nitrogen derived from fertilizer (NFF) in apple (Gala / ten different rootstocks) wood tissue grown at Sturgeon Bay, WI. Trees received $40 \mathrm{~g}$ actual $\mathrm{N}$ fertilizer enriched to $1 \%$ with ${ }^{15} \mathrm{~N}$ in May 1998 (Spring) or Oct. 1998 (Fall). Samples were collected during 1999. $(\mathrm{n}=4$ ).

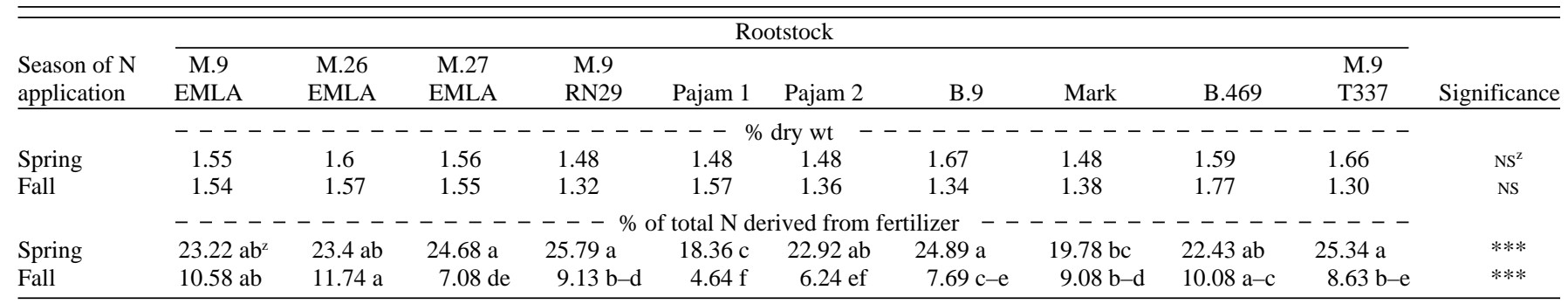

${ }^{2}$ Mean separation within rows by Duncan's multiple range test at $P \leq 0.05$.

${ }_{\text {Ns, } * * *}^{*}$ Nonsignificant or significant at $P \leq 0.001$.

M.9 EMLA, M.26 EMLA, and B.469 were efficient while M.27 EMLA, Pajam 1 and Pajam 2 were inefficient for both leaves and wood.

Among the M.9 clones M.9 EMLA, Pajam 2 and M.9T337 had high NFF in wood following either spring or fall application. Pajam 1 had low wood NFF from both treatment times (Table 4). There were no rootstock differences for wood $\mathrm{N}$ concentration.

In conclusion, our research shows that rootstock had a great effect on N uptake. Different rootstocks had different efficiencies for $\mathrm{N}$ uptake throughout the season. Generally, M.9 EMLA, M.26 EMLA, M.27 EMLA, and B469 were the most efficient in $\mathrm{N}$ uptake and partitioning to leaves regardless the season of $\mathrm{N}$ application. Pajam 1 was the least efficient. Time of application affected the ${ }^{15} \mathrm{~N}$ recovery of both leaf and wood tissue. Applications of fertilizer made in the fall strongly affected the initial $\% \mathrm{~N}$ in new growth. Under the conditions of our study, adequate $\mathrm{N}$ levels in the tissues were only achieved after spring application but fall treatment provided higher $\mathrm{N}$ levels in the early season.

\section{Literature Cited}

Bremner,J.M. 1996. Nitrogen-Total, p. 1085-1121. In: D.L. Sparks (ed.). Methods of soil analysis Part 4: Chemical methods. Soil Sci. Soc. Amer. No. 5. Madison, Wis.

Dong, S., L. Cheng, and L.H. Fuchigami. 1998. Nutrient uptake by new roots of six clonal apple rootstocks. HortScience 34:492.

Hauck, R.D. and J.M. Bremner. 1976. Use of tracer for soil and fertilizer nitrogen research. Adv. Agron. 28:219-266.

Hill-Cottingham D.G. and C.P. Lloyd-Jones. 1975. Nitrogen-15 in apple nutrition. J. Sci. Food and Agr. 26:165-173.

Khemira, H., T.L. Righetti, and A.N. Azarenko. 1998. Nitrogen partitioning in apple as affected by timing and tree growth habit. J. Hort. Sci. and Biotech. 73:217-223.

Millard, P. and M. Thomson. 1989. The effect of autumn senescence of leaves on the internal cycling of nitrogen for the spring growth of apple trees. J. Expt. Bot. 40:1285-1289.

Muños, N., J Guerri, F. Legaz, and E. Primo-Millo. 1993. Seasonal uptake of ${ }^{15} \mathrm{~N}$-nitrate and distribution of absorbed nitrogen in peach trees. Plant \& Soil 150:263-269.

Sanchez, E.E., T.L. Righetti, D. Sugar, and P.B. Lombard. 1990. Seasonal differences, soil tex- ture and uptake of newly absorbed nitrogen in field-grown pear tree. J. Hort. Sci. 65:395-400.

Sanchez, E.E., T.L. Righetti, D. Sugar, and P.B. Lombard. 1991. Recycling of nitrogen in field grown "Comice" pear. J. Hort. Sci. 66:79-486.

Sanchez, E.E., T.L. Righetti, D. Sugar, and P.B. Lombard. 1992. Effect of timing of nitrogen application on nitrogen partitioning between vegetative, reproductive and structural components of mature "Comice" pears. J. Hort. Sci. 67:51-58.

Tagliavini, M., M. Quartieri, and P. Millard. 1997. Remobilized nitrogen and root uptake of nitrate for spring leaf growth, flowers and developing fruits of pear (Pyrus comunis L.) trees. Plant and Soil 195:137-142.

Titus, J.S. and S.M. Kang. 1982. Nitrogen metabolism, translocation and recycling in apple trees. Hort. Rev. 4:204-246.

Tromp, J. and L.C. Ovaa. 1973. Spring mobilization of protein nitrogen in apple bark. Phys. Plantarum 29:1-5.

Weinbaum, S.A., I. Klein, F.E. Broadbent, W.C. Micke, and T.T. Muroaca. 1984. Effect of time of nitrogen application and soil texture on the availability of isotopically labeled fertilizer nitrogen to reproductive and vegetative tissue of mature almond tree. J. Amer. Soc. Hort. Sci. 109:339343. 